\title{
The Integration of Vocabulary and Effective Sentence Mastery towards Students' Argumentative Writing Skills
}

\author{
Tien Rafida \\ English Department, Faculty of Education and Teachers Training \\ UIN North Sumatra \\ titinrafida@gmail.com \\ DOI: http://dx.doi.org/10.18326/rgt.v10i1.1-11
}

\section{ENGLISH ABSTRACT}

The aims of this research is to reveal the integration of vocabulary and effective sentence mastery against the students of English department of Faculty of Education and Teachers Training UIN North Sumatra's argumentative writing skills. This research uses a quantitative approach. The populations are students of English department of 6 classes. The samples in this result are students of class II. By using cluster random sampling, it was obtained a sample of 140 students. The instrument used is a test. These results indicate that: (1) vocabulary mastery contributed positively and significantly to the argumentative essay writing skills of students. The amount of contribution is $18.4 \%$; (2) Effective sentence mastery contribute positively and significantly to the argumentative essay writing skills of students. The amount of contribution is 11.7\%; (3) The mastery of vocabulary and mastery of effective sentences contributed positively and significantly to the argumentative essay writing skills of students. The contribution is $26.5 \%$; (4) mastering vocabulary to effectively contribute by $16.39 \%$ against the argumentative essay writing skills of students; (5) The mastery effective sentence effectively contribute $13.11 \%$ against the argumentative essay writing skills of students. Based on the results of this study, it was concluded that the vocabulary and effective sentences mastery are the two factors that influence the argumentative essay writing skills of students.

Keywords: Vocabulary, Effective sentence mastery, Argumentative writing skills

\section{INDONESIAN ABSTRACT}

Tujuan penelitian ini adalah untuk mengetahui integrasi kosa kata dan penguasaan kalimat yang efektif pada mahasiwa jurusan Bahasa Inggris Fakultas Keguruan dan Ilmu Pendidikan UIN Sumatra Utara dalam kaitannya dengan keterampilan menulis esai argumentatif. Penelitian ini menggunakan pendekatan kuantitatif. Populasinya mahasiswa Jurusan Bahasa Inggris dari 6 kelas. Sampel dalam penelitian ini adaalah mahasiswa kelas II. Dengan menggunakan Cluster Random Sampling, diperoleh sampel sebanyak 140 siswa. Instrumen yang digunakan adalah tes. Hasil penelitian menunjukkan bahwa: (1) penguasaan kosa kata berkontribusi secara positif dan signifikan terhadap keterampilan menulis esai argumentatif mahasiswa. Jumlah kontribusinya adalah 18,4\%; (2) Penguasaan kalimat yang efektif berkontribusi secara positif dan signifikan terhadap keterampilan menulis esai argumentatif mahasiswa. Besarnya kontribusi adalah 11,7\%; (3) Penguasaan kosakata dan penguasaan kalimat efektif memberikan kontribusi positif dan signifikan terhadap kemampuan menulis esai argumentatif mahasiswa. Kontribusinya adalah 26,5\%; (4) menguasai kosakata 
berkontribusi secara efektif sebesar 16,39\% terhadap keterampilan menulis esai argumentatif mahasiswa; (5) Penguasaan kalimat efektif menyumbang 13,11\% terhadap kemampuan menulis esai argumentatif mahasiswa. Berdasarkan hasil penelitian ini, disimpulkan bahwa kosakata dan penguasaan kalimat efektif merupakan dua faktor yang mempengaruhi kemampuan menulis esai argumentatif mahasiswa.

Kata Kunci : Kosakata, Penguasaan kalimat efektif, keterampilan menulis esai argumentatif.

\section{INTRODUCTION}

One person's language skills acquired through the study of English in a campus environment where education takes place, can be characterized by their skills to communicate. Therefore, learning vocabulary and writing should be implemented in to make students skilled language, both oral and written. For that, a student must know that the language consists of grammatical units, namely discourse, sentence, clause, phrase, word, and morpheme.

English Department which is a favorite department in the Faculty of Education and Teaching (FITK) State Islamic University of North Sumatra (UIN-SU). From the results it is observed that the teaching of English is still far from expectations. Not achieving the goal of teaching of English is often perceived by students and the public. Today in our society increasingly audible voices that expressed less satisfied with the results of English teaching.

The phenomenon in teaching of English to hinder the achievement of English teaching came from students, teachers, learning materials, and the implementation of the teaching and learning process.

Actually, the development of writing skills in general has started an advanced course. Thus, students should already have the skills to write well. But in reality, from the observation that researchers do at PBI FITK UIN-SU, can be delivered several observations: 1) unskilled students making up for his mastery of grammatical still weak and vocabulary inadequate, 2) lack of mastery in choosing words and phrases ,3) the use of the sentence and paragraph development in writing is not correct, 4) spelling and punctuation used in the writing not in accordance with the rules, 5) interest in reading books related to the English is still low, and 6) the rarely done exercises and another wrote habituation.

Problems of teaching English that comes from teachers are the shortage of teachers in implementing the learning process, namely: 1) lack of ability of teachers to select and use learning strategies teaching, 2) lack of ability of teachers implement the curriculum in teaching and learning, 3) lack of control of the teachers the subject matter, 4) the teachers who teach in English instead of English education background, and 5) lack of ability of teachers to evaluate student results.

In order to have good writing skills, students are required to have a lot of vocabulary, master standard English spelling, and know how to use of sentences, clauses, and phrases. In concrete terms this research problem can be identified as a lack of mastery in choosing words and expressions, the use of incorrect sentence and paragraph development in writing, inappropriate spelling and punctuation used in writing which is not in accordance with the 
rules, low interest in reading the books related to the English, and it is rare to do exercises and make a writing habit.

A primary issue in this research can be formulated with how great is the contribution made by the vocabulary and the contributions made by the mastery of effective sentences against the argumentative essay writing skills of students of PBI FITK UIN-SU. Simultaneously, this research aims to reveal the magnitude of the vocabulary and effective sentence mastery contribution to the argumentative essay writing skills of students FITK UIN PBI-SU. As research benefits expected to be useful for improving the quality of education and the teaching of English in particular about the vocabulary, sentences, and write the essay, the author can add insight and improve knowledge both theoretically and practically.

\section{Theoretical Review}

Stork (1976: 250) said that the vocabulary was the stock of words which were at the disposal of a speaker or writer. The terms refer to my vocabulary all words and phrases were used such as a particular variety-dialect-register, or terminology: a vocabulary word of inventory owned by the writer or speaker. That term refers to whole words, phrases were used in specific variations such as: dialects, registers, or in general terms.

Furthermore, Dale (in Tarin, 1989: 23) was suggested several techniques that could be done in the development of the vocabulary of students, namely: (1) the need as teaching, (2) the user context, (3) synonyms, antonyms, hyponymy, (4) the origin of the word, (5) prefixes, (6) suffix, (7) the root of the word, (8) the words and spelling, (9) semantics, (10) figure of speech, (11) literature and vocabulary development, (12) the use of dictionaries and (13) a play on words.

In an effort to increase the quantity and quality of student vocabulary are actually all of these techniques can be used. However, in order that the technique could be used in accordance with the matter to be assessed, it should be selected in advance whether it is appropriate techniques are used or not.

\section{Effective Sentence}

The sentence is the main element of a discourse (Ambo Enre, 1988: 75). It is true to say that we must first learn to recognize words before the start stringing a sentence, but the sentence stating that we want to express meaning. The meaning is not the same as the number of words that make sense. Mc Wharter (1980: 57) explained that the sentence as a set of words express the unity of thoughts or ideas. A minimum number of sentence consisted of a subject and an activity associated with the subject which he called a predicate. Simultaneously elements of subject and predicate form the core parts are the core element of a sentence that carries significance (Keraf, 1990: 35), (Keraf, 1990:35 \& Oshima, 1991:74). 
Similarly, Sugono (1998: 89) stated that a sentence should meet the requirements of grammatical construction. That means that the sentence should be arranged based on the correct rules which include: (a) the elements in a sentence, (b) the application of the correct spelling, and (c) selecting the right words in a sentence.

\section{Argumentative Essay Writing}

Writing as one of the components of language skills, requiring the expertise of a person in using a form of written language for communication purposes (Keraf, 1990: 42). Furthermore, Halim et al. (1974: 35) added that writing skills are the skills to organize and express the elements as follows: (1) the content of the article, (2) the form of essays, (3) grammar, (4) style or choice of structure and vocabulary, and (5) the application of spelling and punctuation.

\section{METHODS \& DISCUSSION}

The following is the description of histogram distribution of variable frequency vocabulary such as,

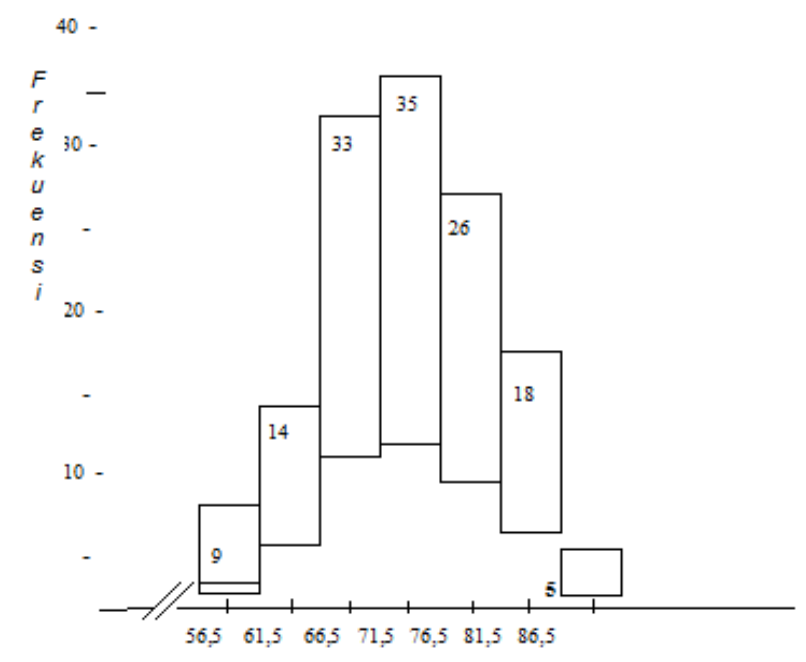

In te rval Class

\section{Figure 1: Frequency Distribution Histogram Values Vocabulary Mastery}

From the calculation done to be obtained $24.3 \%$ (34 students) including a group of high, 59.3\% (83 students) including a group of moderate, and 16.4\% (23 students) belong to a group that received a low score. 


\section{Effective Sentence Mastery}

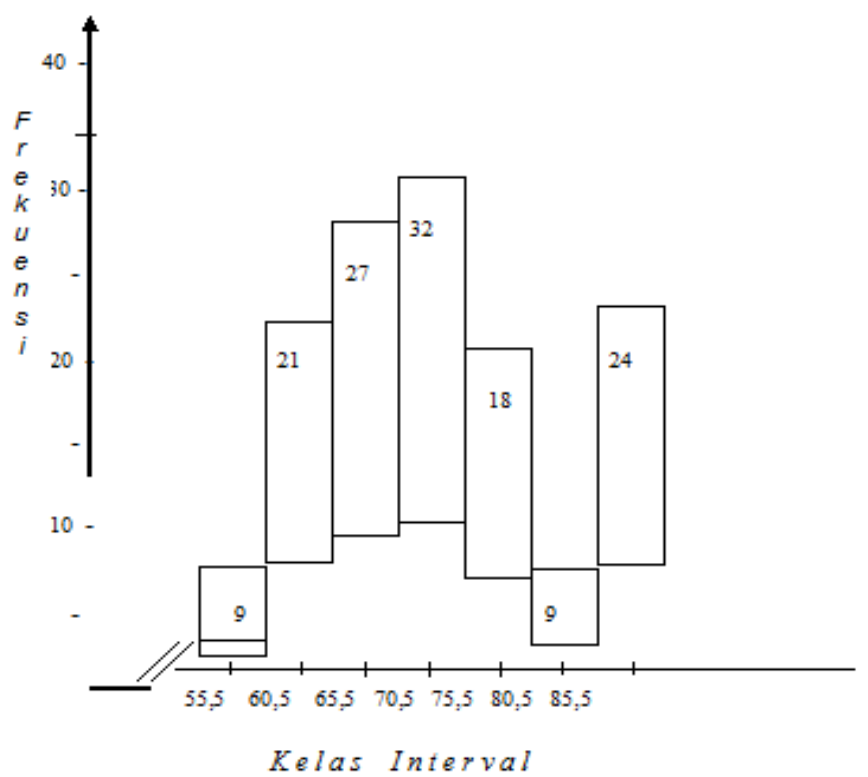

Figure 2: Frequency Distribution Histogram Sentence Mastery Value Effective

From the results of calculations carried a picture that $23.6 \%$ (33 students) belong to a group that earns high marks, $55.0 \%$ (77 students) including a group of moderate, and $21.4 \%$ (30 students), including low groups, Data

\section{Argumentative Essay Writing Skills}

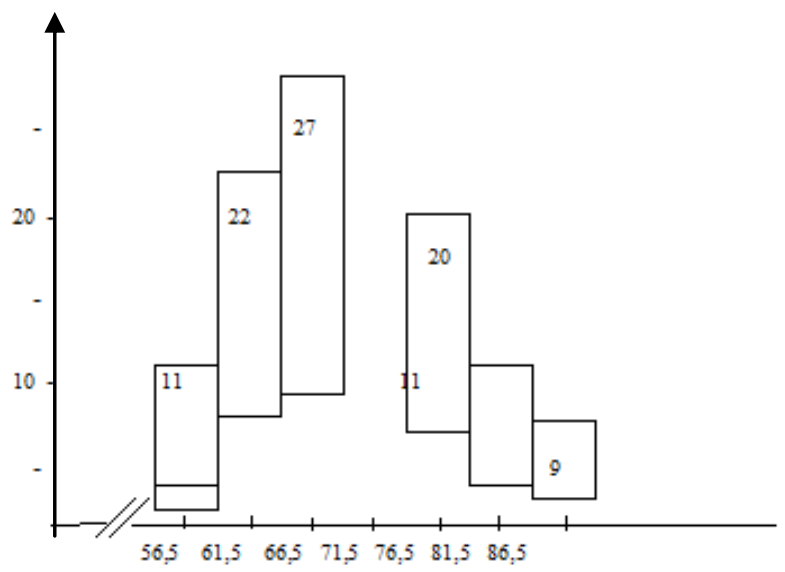

In te r v a l Class 


\section{Figure 3: Histogram Frequency Distribution of Skills}

From the results of the calculations have been made to know that $15.0 \%$ (21 students) including a group of high, $64.3 \%$ (90 students) including a mediocre group and $20.7 \%$ (29 students) included in the low group. These data show that students in essay writing skills of argumentation in general are in the moderate group.

Furthermore, based on the level of understanding that is obtained from the average value with a maximum value is obtained tendency essay writing skills of argumentation Indonesian students were in enough categories, namely $79.39 \%$. Curve Estimation Simple Regression Line Equations Variable X1 with Y

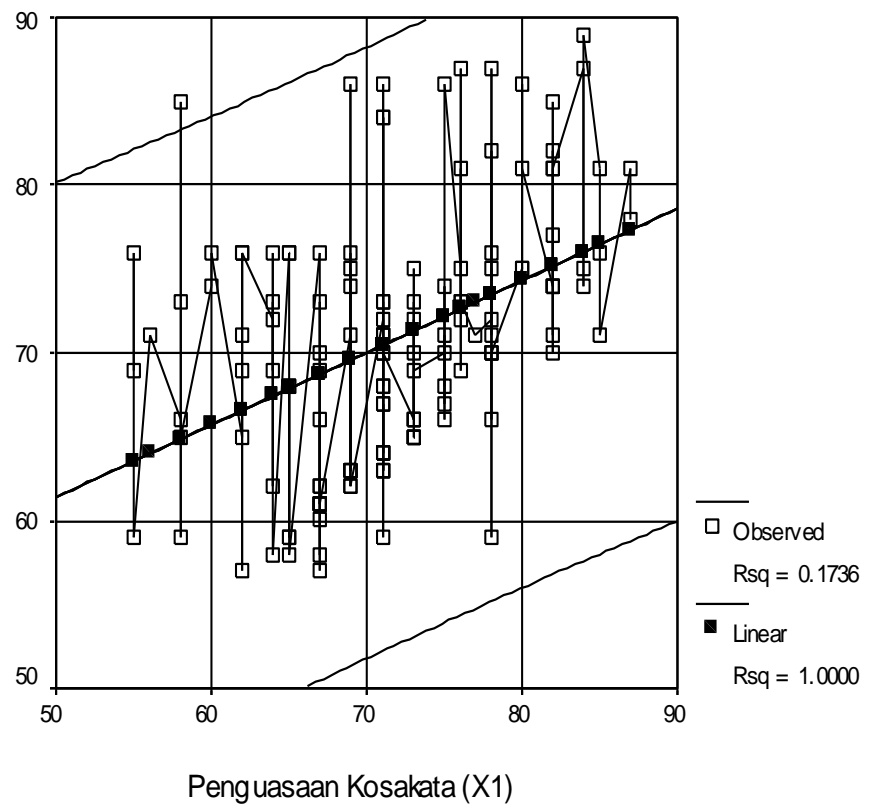

\section{Figure 4: Distribution of Variable Data Mastery vocabulary}

The picture above may explain the paradigm of the formation of the relationship variables mastery of vocabulary by using the arguments writing skill that are in the reception area which is linear and only one point that is outside the linear region (data extreme) which is used as a point prediction in order to establish the contribution vocabulary mastery of the skills wrote an essay arguing.

Contributions Mastery Sentence Writing Skills Writing Effective against Arguments
A. Curve Estimation Equation simple regression lines
B. Variable X2 with Y 


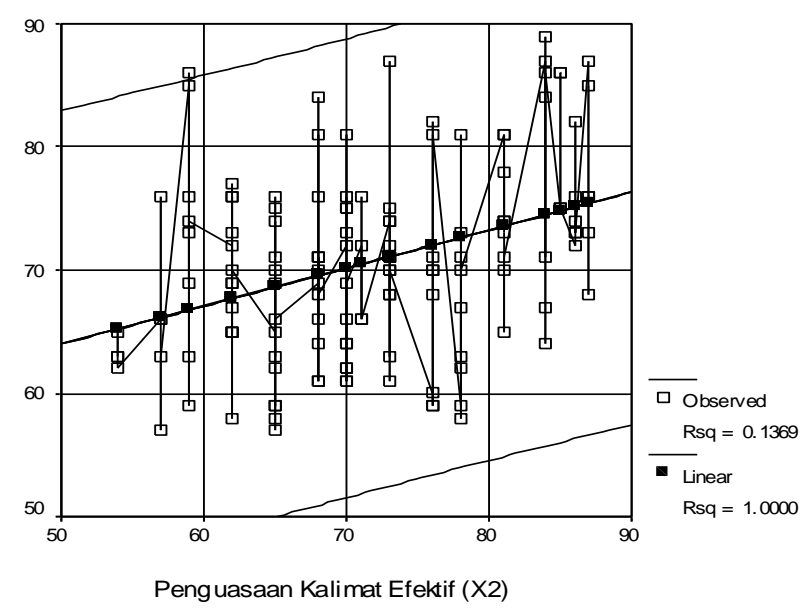

\section{Figure 5: Distribution of Variable Data X2 and Y}

From the above it can be concluded that the effective sentence has a positive and significant relationship with determination coefficient of 0.137 . This means that the argument essay writing skills of students $13,7 \% \%$ determined by the mastery of effective sentences and the balance of $86.3 \%$ is determined by other factors.

\section{The Contributions of Vocabulary and Effective Sentence Mastery towards Argumentative Essay Writing Skills}

From this regression equation can be concluded that the vocabulary and mastery of effective sentences together against the argument essay writing skills of the student has a significant relationship. The coefficient of determination obtained at 0.275 indicates that the argument essay writing skills of students is determined by the vocabulary and mastery of their effective sentence against the argument essay writing skills by $27.5 \%$, and the remaining $72.5 \%$ is influenced by other factors.

\section{Effective \& Relative Contributions to the Variable Bound Variables}

Effective and relative contribution of each independent variable on the dependent variable. Although the terms of the empirical seen that the vocabulary and mastery of effective sentence of students to skills of arguments essay writing skill make a meaningful contribution, but due to the nature test in capturing vocabulary, effective sentence mastery and essay form provided with materials and topics are limited, so the vocabulary and arguments mastery of effective sentences and essay writing skills of students of PBI UIN-SU still need to be improved.

The independent variables are measured with test vocabulary and mastery of effective sentences students. The instrument of this research is in the form of a test. Problem for 
vocabulary tests of 60 questions (in the form of matching words as much as 30 multiplechoice questions and 30 questions), while the question to test the mastery of effective sentence in the form of multiple-choice questions numbered 40. As for student essay writing skills test, asked for an essay based on the title that has been provided.

The trials are valid and reliable instrument in accordance with procedures implementation, such as: (1) the determination of sample testing, (2) the implementation of the trial, (3) analysis of the trial, and (4) the results of testing the validity and reliability of the instrument. While the data analysis technique using simple regression techniques and multiple regression and partial correlation techniques. The Tools for analyzing the data also using SPSS version 11.0 for Windows.

Dealing with the relationship among these three variables can be seen in the following diagram:

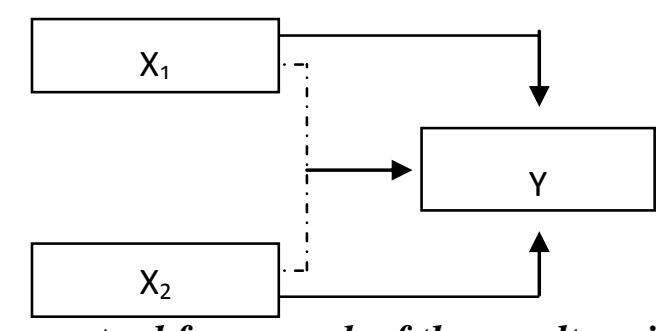

Figure 6: The conceptual framework of the result variables third link Information:

$X 1=$ Mastery Vocabulary

$X 2=$ Mastery Effective Sentences

$Y=$ Arguments Essay Writing Skills

\section{CONCLUSIONS}

The conclusion of the result can be expressed as follows: 1. Vocabulary mastery (X1) has a positive and significant contribution to the argument essay writing skills (Y). This shows that the vocabulary (X1) consistently contribute directly to the arguments essay writing mastery (Y). Therefore, if the level of student mastery of vocabulary is good, the better the argument essay writing skills of students' FITK UIN PBI-SU 2. The Mastery of effective sentence (X2) has a positive and significant contribution to the argument essay writing skills (Y). This shows that the mastery of effective sentences (X2) consistently also contribute directly to the student's argument essay writing skills (Y). Therefore, the better the level of student mastery of effective sentences, the better the argument essay writing skills mastery students' FITK UIN PBI-SU

3. The Mastery of vocabulary (X1) and mastery of effective sentences (X2) together have a positive and significant contribution to the student's argument essay writing skills (Y). This shows that the vocabulary (X1) and mastery of effective sentences (X2) consistently 
contribute directly to the argument essay writing skills (Y). Therefore, the better the student mastery of vocabulary and sentence effectively, the better the skill level of argumentation essay writing student FITK UIN PBI-SU.

\section{REFERENCES}

Adams, M. J. (1990). Beginning to read: Thinking and learning about print. Cambridge, MA: MIT Press.

Anderson-Yockel, J., \& Haynes, W. (1994). Joint-picture book reading strategies in working-class. New York.Wiley.

African American and white mother-toddler dyads. Journal of Speech, Language, and Hearing Research, 37, 583-593.New York. Wiley.

Baugh, J. (2001). Coming full circle: Some circumstances pertaining to low literacy achievement among African Americans. In J. Harris, A. Kamhi, \& K. Pollock (Eds.), Literacy in African American communities (pp. 277-288). Hillsdale, NJ:

Erlbaum. Bloom, L., \& Lahey, M. (1978).Language development and language disorders. New York: Wiley.

Bloome, D., Champion, T., Katz, L., Morton, M. B., \& Muldrow, R. (2001). Spoken and written narrative development: African American preschoolers as sto- rytellers and storymakers. In J. Harris, A. Kamhi, \& K. Pollock (Eds.), Literacy in African American communities (pp. 45-76). Hillsdale, NJ: Erlbaum.

Brown, I. S., \& Felton, R. H. (1990). Effective instruction $n$ beginning reading skills in children at risk for reading disability. Reading and Writing, 2,223-241.

Brown, R. (1973). A first language: The early stages. Cambridge, MA: Harvard University Press.

Bus, A. G., van IJzendoorn, M. H., \& Pelligrini, A. D. (1995).`Joint book reading makes for success in learning to read: A meta-analysis on intergenerational transmission of literacy. Review of Educational Research, 65, 1-21

Cecil,N.L.(1988). Black dialect \& academic success: A study of teacher expectations. Reading Improvement, 25, 34-38. 
Craig, H. K., Connor, C. M.,\&Washington, J. A.(2003). Early positive predictors of later reading comprehension for African American students: A preliminary investigation. Language, Speech, and Hearing Services in Schools, 34, 31-43.

Dunn, L., \& Dunn, L. (1981). Peabody Picture Vocabulary Test Revised. Circle Pines, MN: American Guidance Service.

Foorman, B. R., Francis, D. J., Fletcher, J. M., Schatschneider, C., \& Mehta, P.(1998). The role of instruction in learning to read: Preventing reading failure in at-risk children. Journal of Educational Psychology, 90, 37-55.

Gemake, J. S. (1981).Interference of certain dialect elements with reading comprehension for third graders. Reading Improvement, 18, 183-189.

Grigg, W. S., Daane, M. C., Jin, Y., \& Campbell, J. R. (2003). The nation's report card: Reading 2002 (NCES 2003-521). Washington, DC: U.S. Department of Education, Institute of Education Sciences, National Center for Education Statistics.

Harber, J. R. (1977). Influence of presentation dialect and orthographic form on reading performance of black, inner-city children. Educational Research Quarterly, 2(2), 916.

Heath, S. B. (1983). Ways with Words. Cambridge, UK: Cambridge University Press.

Markham, L. (1984). De dog and De cat: Assisting speakers of Black English as they begin to write. Young Children, 39(4), 15-24.

Melmed, P. J. (1973). Black English phonology: The question of reading interference. In J. L. Laffey \& R. W. Shuy (Eds.), Language differences: Do they interfere? (pp. 70-85). Newark, DE: International Reading Association.

Pike, K. (1967). Language in relation to a unified theory of the structure of human behavior. The Hague: Mouton.

Sameroff, A. J., Seifer, R., Barocas, R., Zax, M., \& Greenspan, S. (1987). Intelligence quotient scores of 4-year-old children: Social environmental risk factors. Pediatrics, 79, 343-350.

Simons, H. D., \& Johnson, K. R. (1973). Black English syntax and reading interference. Research in the Teaching of English, 8, 339-358. 
Snow, C., Burns, S., \& Griffin, M. (1998). Preventing reading difficulties in young children. Washington, DC: National Academy Press.

Stockman, I. J. (1996). Phonological development and disorders in African American children. In A. G. Kamhi, K. E. Pollock, \& J. L. Harris (Eds.), Com munication development and disorders in African American children (pp. 117-153). Baltimore: Brookes.

Thompson, C. A. (2003). The oral vocabulary abilities of skilled and unskilled African American readers. Unpublished doctoral dissertation, University of Michigan, Ann Arbor.

Washington, J. A., \& Craig, H. K. (1992). Performances of low-income, African American preschool and kindergarten children on the Peabody Picture Vocabulary Tests-Revised. Language, Speech, and Hearing Services in Schools, 23, 329-333.

Woodcock,R.W. (1987). Woodcock Reading Mastery Tests-Revised. Circle Pines, MN: New York. American Guidance Service. 